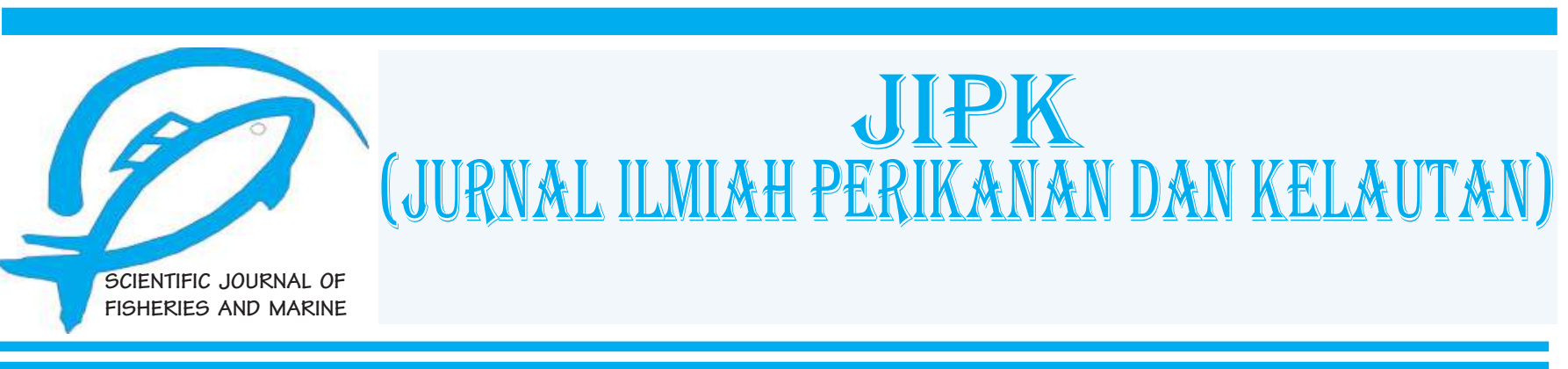

Research Article

\title{
Chemical-Physical Properties Characterization of White Snapper Fish Skin Rambak Crackers Based on Boiling and Drying Duration
}

\section{Hardoko iD, Sri Utami}

Teknologi Hasil Perikanan, Fakultas Perikanan dan Ilmu Kelautan, Universitas Brawijaya. Indonesia

\section{OPEN}

\section{ACCESS}

\section{ARTICLE INFO}

Received: Desember 25, 2019

Accepted: January 22, 2020

Published: March 11, 2020

*) Corresponding author:

E-mail: hardoko@ub.ac.id

\section{Keywords:}

chemical-physical propertiesrambak cracker

white snapper fish skin

drying

boiling

This is an open access article under the CC BY-NC-ND license (http://creativecommons.org/licenses/by-nc-nd/4.0/)

\begin{abstract}
Fish skin is a byproduct of fish filet production, its use is still limited, but some of the terrestrial animal skin is partially processed into rambak crackers, which is quite well known in Indonesia. The purpose of this study was to determine the duration of boiling and drying time on the chemical-physical properties of rambak crackers from white snapper skin. The research method used was an experiment with a boiling time treatment of $0,10,15$, and 20 minutes and drying time with 10,20, and 30 hours in sunlight. The results showed that the boiling time and drying duration had an effect on the chemical-physical properties of the rambak crackers of white snapper fish skin. The resulting rambak crackers have physical characteristics of 15.13-25.39 N/ m2, 70.44-100.07\% enlarging capacity, and chemical characteristics of the water content was $1.09-4.95 \%$, protein content of $65.26-70.43 \%$, and fat content of $13.43-15.83 \%$. The best crackers are those which resulted from 30 minutes of boiling and 30 hours of frying process with a fracture limit of $15.13 \mathrm{~N} / \mathrm{m} 2$, an enlarging capacity of $100.07 \%$, moisture content of $1.09 \%$, protein content of $66.25 \%$, and fat content of $13.43 \%$.
\end{abstract}

Cite this as: Hardoko, \& Utami, S. (2020). Chemical-Physical Properties Characterization of White Snapper Fish Skin Rambak Crackers Based on Boiling and Drying Duration. Jurnal Ilmiah Perikanan dan Kelautan, 12(1):122-130. http://doi.org/10.20473/ jipk.v12i1.14842 


\section{Introduction}

White snapper is a high economic value marine fishery commodity with an increasing production volume. Based on the 2013 performance report of the Ministry of Maritime Affairs and Fisheries, the total volume of national capture fisheries production in 2012 amounted to 5,435,632 tons. The volume increased from 109,299 tons in 2008 to 119,008 tons in 2012 . With the increase in the capture, this would have an impact on the development of the snapper processing industry as part of capture fisheries.

White snapper, both in the form of fresh and processed, were increasing in demand in the domestic and foreign markets. Currently, the white snappers were mostly processed by the filet industry in fresh and also frozen conditions. The development of the filet industry could produce quite a lot of waste, namely waste in the form of fish heads, bones, meat, entrails, and fish scales (Rostini, 2013). The waste could still be used as raw material for food or feed products and other derivative products. In addition to these wastes, there were byproducts in the form of fish skin which could be used as tanned leather (Setiawan et al., 2015; Khamidah et al., 2015), sources of gelatin (Nasution et al., 2018; Sugihartono, 2014; Trilaksani et al., 2012; Oktaviani et al., 2017; Gunawan et al., 2017), and rambak fish skin crackers' (Safitri et al., 2019; Purnamayati et al., 2018; Widyatami and Wiguna, 2016; Kristianingrum et al., 2006; Agustina and Saputro, 2018; Huda et al., 2006). The process of making fish skin gelatin was quite long, and its quality was still inferior to gelatin from the skin of land animals (Sugihartono, 2014) and also in the process of tanning fish skin. Thus, the rambak fish skin cracker would be an option for processing fish skins because the process was simple and easy for people and small industries to do.

Fish skin rambak crackers could generally be made from pelagic or demersal fish (Kaewmanee et al., 2015), freshwater fish, and seawater fish (Safitri et al., 2019; Kristianingrum et al., 2006). The process of making fish skin rambak crackers were varied greatly from the simplest to those who try to follow the method of making crackers for land animals skin like cattle, buffalo, pigs, and others. The simple process of making the fish skin crackers was to dry the fish skin and then fry it (Kristianingrum et al., 2006). Another process of making the fish skin crackers referred to making the fish skin crackers using acid or base treatment, boiling and drying (Amertyaningtyas, 2011; Safitri et al., 2019). Acid or base treatment on land animal skins aimed to facilitate the removal of fur and also for the development of the skin.
Fur or hair on animal skin was easily pulled out because of the development of the skin due to acid or base treatment. The negative effect of lime was the bitter taste when it was not clean enough when rinsing the lime. The negative effect of acid was that it could break the collagen or gelatin protein so it may damage the structure of the skin and caused skin crackers to enlarge less. Therefore, it should be considered not to use acids or bases treatments in the processing of rambak fish skin crackers.

About fish skin, in general, the characteristics of fish skin was thin skin, had less collagen content, and as strong as cow or buffalo skin or pig skin. Also, there was no fur on the skin of the fish, so in the process of making rambak fish skin crackers need to be considered not to use acid or base treatment. Another consideration supporting the elimination of acid-base treatment was the statement of Widati et al. (2007) that in the process of boiling the skin, the amount of water absorbed would change the skin's collagen protein into gelatin which would affect the level of enlargement and crunchiness of the resulting crackers. Therefore, this research needed to be done to determine the effect of the boiling and drying process duration on the chemical-physical properties or characteristics of crackers of white snapper fish skin. The chemical-physical properties measured in the rambak crackers included the breaking strength, enlargement, water content, protein content, and fat content.

\section{Materials and Methods}

\subsection{White snapper skin}

The material used in this study was the skin of white snapper, cooking oil (Special Bimoli brand), garlic, table salt. White snapper skin was obtained from one of the snapper fillet processing companies in Pasuruan, East Java.

\subsection{Experimental Design}

The method used is an experimental method with independent variables in the form of boiling duration and drying duration with sunlight, while the dependent variable was physical properties (fracture strength and enlargement) and chemical properties (water content, protein content, and fat content).

The experimental design used was a $4 \times 3$ Factorial Complete Randomized Design with three replications. The treatment factor consisted of boiling duration (A) and sun drying duration. The boiling duration factor consisted of 4 levels (A1 $=0$ minutes, $\mathrm{A} 2=10$ minutes, $\mathrm{A} 3=15$ minutes and $\mathrm{A} 4=20$ minutes) and the drying duration factor (B) consists of 3 levels (B1 $=10$ hours, $\mathrm{B} 2=20$ hours and B3 $=30$ hours). The data obtained 
were analyzed by analysis of variance (Anova). If there was a significantly different effect on the level of confidence of $5 \%$ of variance, Tukey testing would take place afterward.

\subsection{Making Fish Skin Rambak Crackers}

The process of making fish skin crackers in the first phase was hereby referring to the research of Taufiq et al. (2015) and modified according to the treatment applied. The initial process carried out was leaching of snapper skin and removal of scales. Cleaning the skin and cutting it into pieces for $2 \times 2 \mathrm{~cm}$ and then boiling in boiling water for according to the treatment ( 0 minute, 10 minutes, 15 minutes, 20 minutes), and then soaking in a condiment solution (5\% garlic, $2 \%$ salt and water) for 5 minutes. Fish skin that has been seasoned was then drained and dried in the sun according to treatment (10 hours, 20 hours, 30 hours). After drying, fish skins were fried in two stages. The fish skin crackers were fried at $\pm 80 \mathrm{oC}$ for about 2 minutes and then re-fried it in hot cooking oil at $\pm 170^{\circ} \mathrm{C}$ until it has fully enlarged. Then their physical and chemical properties were analyzed.

\section{Results and Discussion}

\subsection{Fracture Strength}

Fracture strength provide clues of the ease of rambak fish skin crackers to be broken. The higher the value of the fracture strength indicates the rambak skin fish cracker was more difficult to be broken and vice versa for the value of the smaller fracture strength, the easier it was to be broken. The value of the fracture strength was also related to the value of product durability (Rosiani et al., 2015). The fracture strength of rambak fish skin crackers value was made based on boiling and sun drying duration, as presented in Figure 1.

In Figure 1, it could be seen that the value of the breaking power tend to decrease with the increase in boiling and also drying duration but increase after the boiling duration of 15 minutes. The fracture strength phenomenon was related to the enlargement capability and porosity of rambak crackers, where the fracture strength was lower, the enlargement capability is higher (Figure 2). The fracture power was also related to the content and nature of collagen found in the skin, where collagen was the dominant amount in fish skin (Said et al., 2016) and was a constituent of $80 \%$ of fish skin protein (Kolanus et al., 2019). The nature of collagen was that it would expand when immersed and heated (Ariyanti et al., 2018). The large development of collagen would affect the fracture strength of rambak fish skin crackers. The lowest fracture value was the result of boiling 15 minutes and drying for 30 hours with a value of $15.13 \mathrm{~N} / \mathrm{m} 2$.
The results also showed that the fracture strength of the rambak fish skin crackers decreased with the addition of boiling and drying duration. The value of fracture strength also connoted the crunchiness of the crisp crackers. The value of crispness getting smaller or lower indicated crackers are more crispy, and conversely, the higher, the crackers are not crispy or harder (Rosiani et al., 2015).

According to Nurwahyuningsih (2010), the higher the enlargement capability, the higher the crispness of a material. Crackers that enlarged would form air cavities in it. The more air cavities that were formed, the more easily it is broken, then the crispness would be higher. The fracture strength of the skin crackers was in the range of $10.60-20.57 \mathrm{~N} / \mathrm{m} 2$ (Hartati, 2018).

\subsection{Enlargement Capability}

The cracker enlargement capacity of the rambak fish skin was affected by collagen content, moisture content, and heat or heating temperature. The fracture strength of the rambak fish skin crackers was also related to the power of skin enlargement during boiling, where the skin's enlargement capacity during boiling was also influenced by acid treatment or base treatment of the skin before boiling (Ariyanti et al., 2018; Kolanus et al., 2019). The cracker development capacity of rambak fish skin crackers of white snapper based on boiling and drying duration is presented in Figure 2.

Figure 2 showed the phenomenon of enlargement capacity of white snapper fish skin rambak cracker which was negatively correlated to fracture power (Figure 1), where the cracker development capacity increased until the boiling duration was 15 minutes and the drying time was 30 hours, then decreased again after that otherwise, the breaking power increased until the boiling time was 15 minutes and decreased after that.

The highest enlargement capacity was obtained at 15 minutes boiling treatment with 30 hours of drying, which resulted in the value of $100.07 \%$. Decrease of enlargement capacity during a boiling time of $20 \mathrm{~min}-$ utes allegedly at the 20th minute collagen in fish skin experiences gelatinization through or excessive during the boiling process so that the development power has decreased.

Excessive gelatinization will damage the structure of gelatin and dissolve protein, so that skin crackers were less able to enlarge when it was fried. Widati et al. (2007) stated that the amount of water absorbed in the process of boiling the skin would change the skin's collagen protein into gelatin, which would affect the level of enlargement and crispness of the resulting fish skin crackers. Aryanti et al. (2018) stated that the 


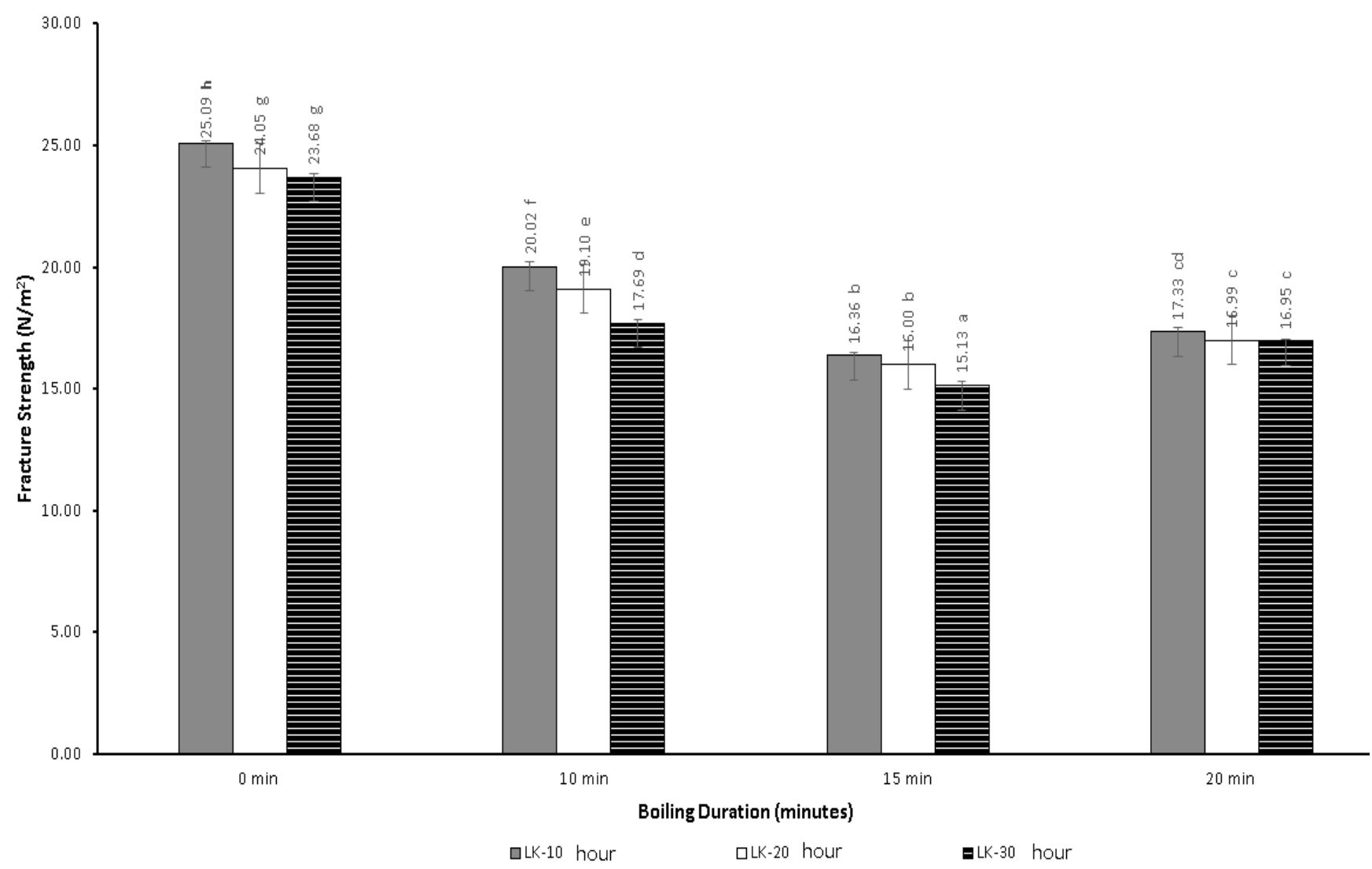

Figure 1. Graph of the fracture strength of rambak fish skin crackers. Description: DD = Drying Duration, the letter notation behind the value indicates the real difference $\mathrm{p}<0.05$

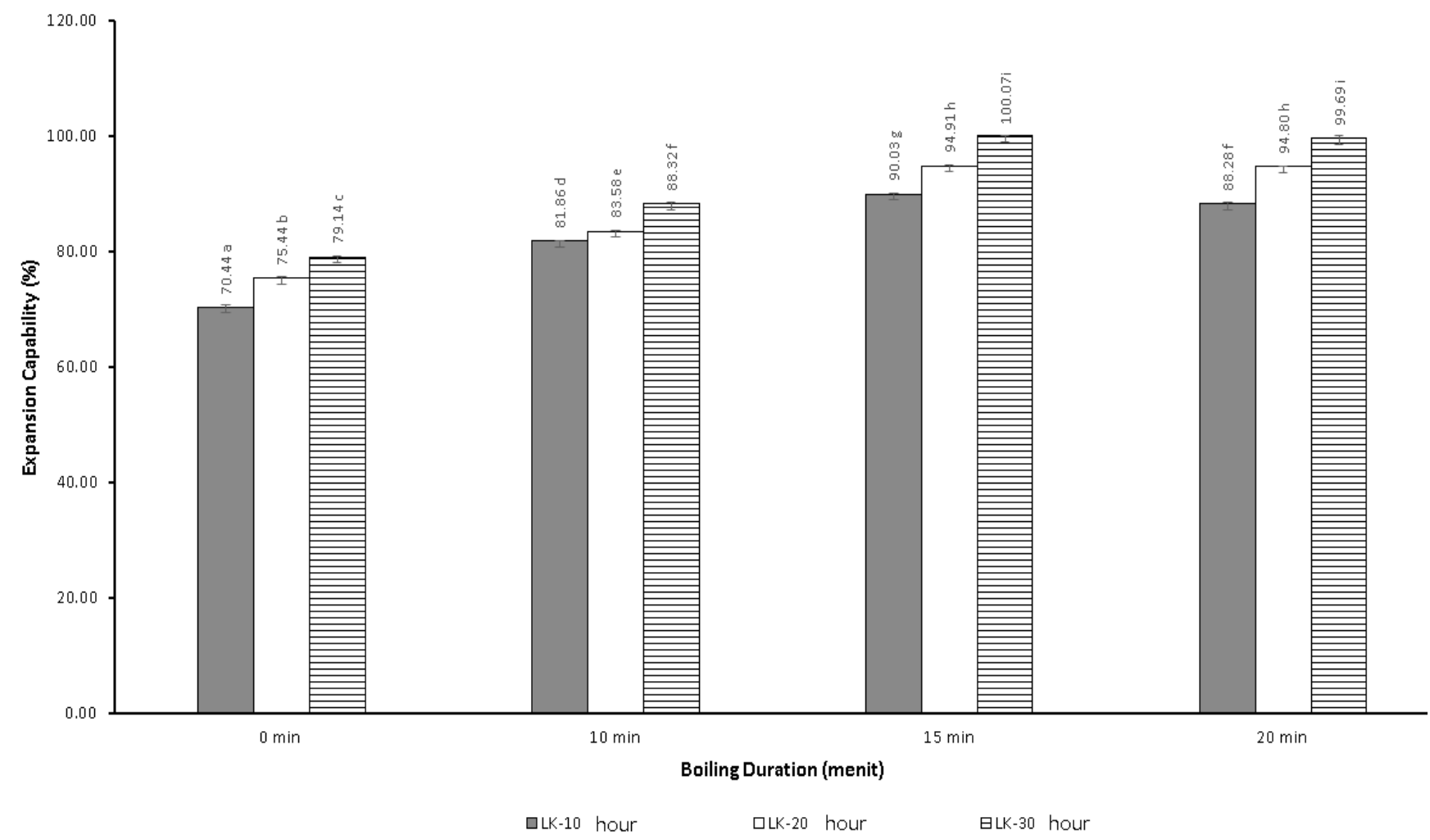

Figure 2: Graphs of white snapper fish skin rambak crackers enlargement capacity based on boiling and sun drying duration. Description: $\mathrm{DD}=$ Drying Duration, The letter notation behind the value indicates a significant difference $\mathrm{p}<0.05$ 


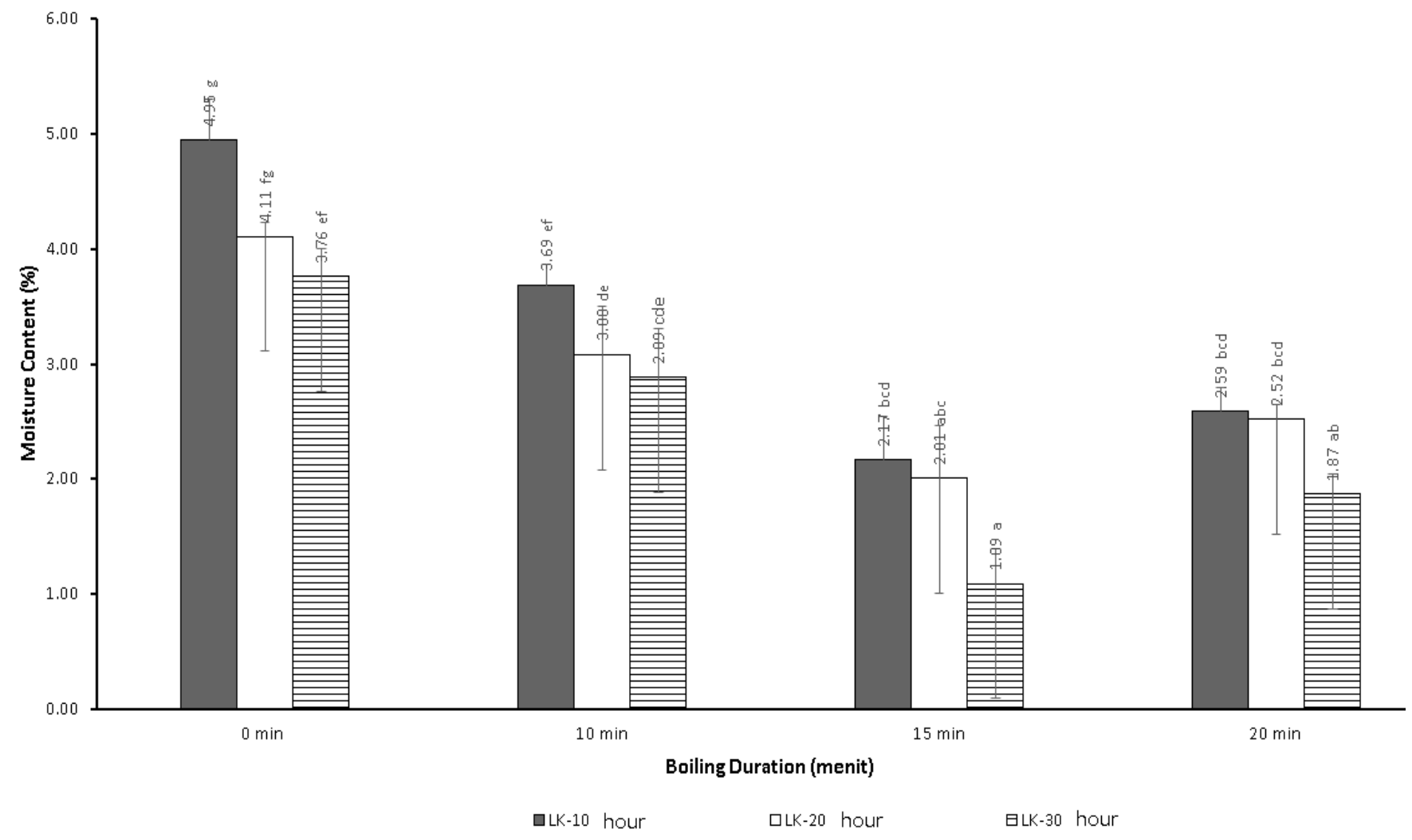

Figure 3. Graph of the moisture content of white snapper fish skin rambak crackers. Description : DD = Drying duration, the letter notation behind the value indicates a significant difference $\mathrm{p}<0.05$

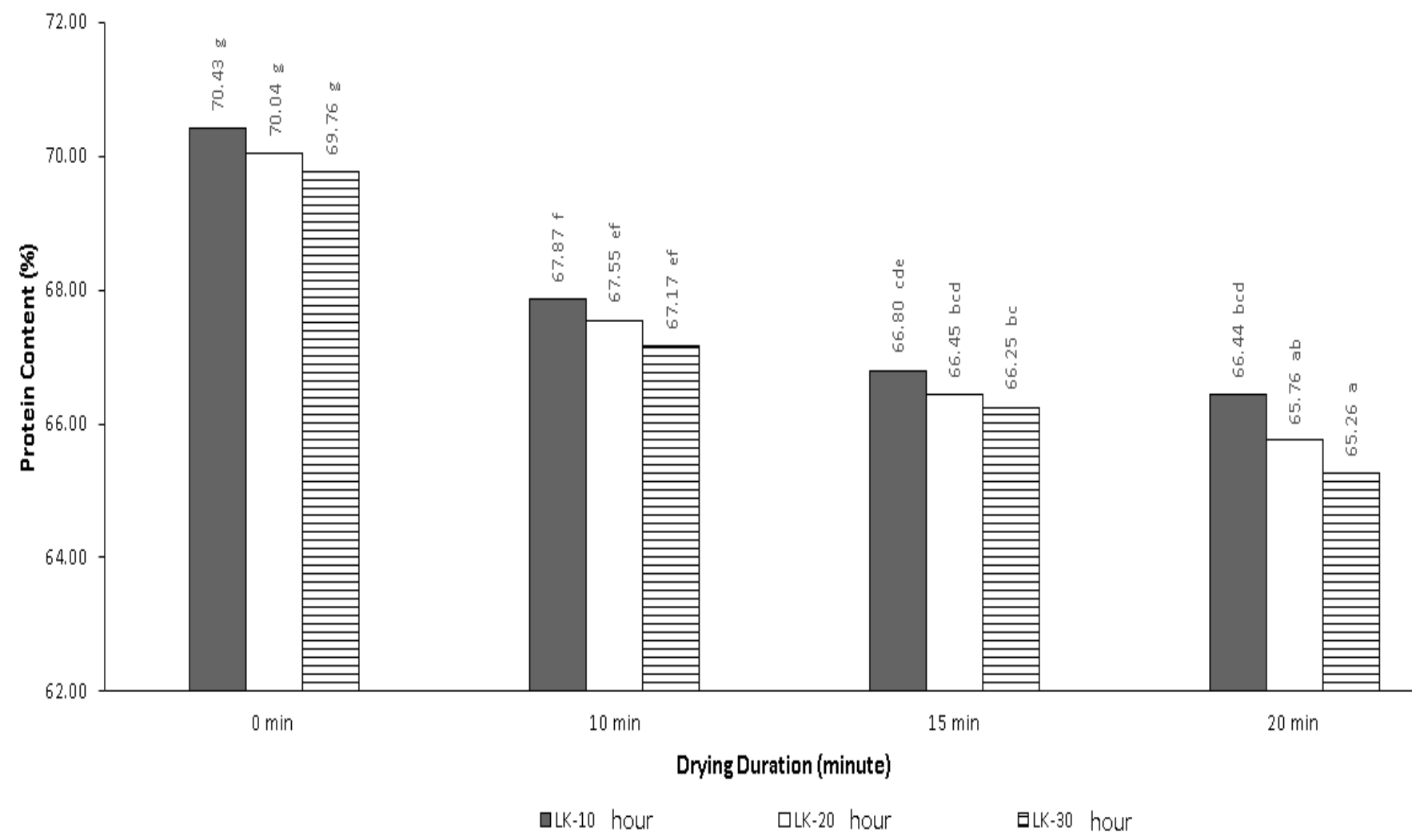

Figure 4. Graph of the protein content of white snapper fish skin rambak crackers. Description : DD = Drying Duration, the letter notation behind the value indicates a significant difference $\mathbf{p}<0.05$ 
enlargement capability was also related to the water content of crackers before frying, where the lower the water content of the crackers, the higher the developmental power. As for Harsono (2006) stated that the volume of cracker enlargement was strongly influenced by the fat content found in fish, the lower the fat content, the lower the volume of cracker development.

There was no standard for cracker enlargement capacity, but as an illustration, the performance of tilapia skin crackers is $13.07-42.93 \%$ (Safitri et al., 2019) so that the enlargement capability of white snapper fish skin rambak crackers is higher, namely the highest the value of the back power reaches $100.07 \%$.

\subsection{Moisture Content}

The moisture content of the rambak fish skin was affected by the duration of boiling and drying duration. Boiling would result in the development of the skin so that the structure of the skin was hollow, and the pores of the skin were more dilated, so that water would easily come out when drying. The moisture content of the rambak white snapper fish skin crackers based on boiling and drying duration can be seen in Figure 3.

Figure 3 showed a decrease in the water content of the rambak crackers on the skin of the snapper until the boiling time is 15 minutes and then rising again at the boiling time of 20 minutes. The decrease in water content is caused by the structure of the protein which is more hollow and larger pores so that the water content that comes out when frying is increased, while the increase in water content at 20 minutes boiling is thought to be caused by denaturation of the excess collagen protein (Ariyanti et al., 2018), reducing the hollow structure and inhibit the release of water when frying. The lowest water content was obtained at 15 minutes boiling and 30 hours drying with a value of $1.09 \%$. The lowest water content turned out to produce the lowest fracture power (Figure 1) and the highest expandability (Figure 2).

When compared with the standards required by SNI 01-2713-1999 concerning fish crackers, which state the maximum water content is $11 \%$, the value of the rambak crackers on snapper skin in this study still meets the standards. Likewise, when compared with SNI 014308-19961 concerning the quality of rambak crackers (BSN, 1996), which requires a maximum water content of $8 \%$. The results of the water content are also still under research by Zulfahmi et al. (2014), which ranged from 5-9\%. High and low levels of cracker water, according to Salamah et al. (2008), are influenced by several things, including the humidity of the air around the material, the level of thickness, and texture of the mate- rial when drying.

If the water content is too high or exceeds the standard, it will reduce the shelf life of crackers. The high water content will accelerate the process of fat hydrolysis and fatty acid oxidation which makes the product more rancid (Fenema, 1996; deMan, 1999).

\subsection{Protein Content}

The high or low protein content of a material can be influenced by the level of protein denaturation, changes in relative proportions with other ingredients, and the density of the material. Protein levels of the rambak cracker skin of white snapper fish skin at various boiling and drying periods can be seen in Figure 4. Figure 4 showed that the value of protein has decreased along with the increasing time of boiling and also drying.

The decrease in protein levels of rambak crackers could be caused by a combination of a greater degree of denaturation by the boiling process, enlargement process (product density), and also the relative proportion with fat and carbohydrates, and the skin collagen content.

According to Gilnatya (2002), the protein content of tuna skin crackers ranges from 59.53\% - 67.05\%. This is thought to be due to the thickness of the dermis (corium) layer, which is almost the same, and the collagen content. According to Widati et al. (2007), collagen protein levels will affect the volume of enlargement of rambak crackers; the higher the collagen, more crispy the cracker will be. The protein content required in SNI 01-2713-1999 for fish crackers is a minimum of 8.0\% (BSN, 1999), whereas according to SNI 01-4308-1996 concerning shrimp crackers (BSN, 1996) it does not require protein content in the quality of fish crackers.

Gadi et al. (2017) stated that collagen proteins have four components of the secondary structure of proteins, namely $\alpha$-helices, $\beta$-sheets, $\beta$-turns, and random overlapping coils. Collagen from tuna fish skin has a $\beta$-sheet structure that has not been denatured to $\alpha$-helix, which is a hallmark of gelatin. The stability of the triple helix in collagen depended on the hydrogen bonds present (Krishnamoorthia et al., 2017). That structure played a role in the process of developing skin crackers. Excessive gelatinization by boiling will result in damage to the gelatin structure and solubility of the protein, thereby reducing the level of the protein rambak crackers.

According to Muin (2014), the protein content of buffalo skin cracker cracks ranged from 73.22 to $79.41 \%$, so the protein content of the white snapper fish skin rambak crackers was lower than that of buffalo skin ripples. This was related to the difference in collagen content between the two skins. 


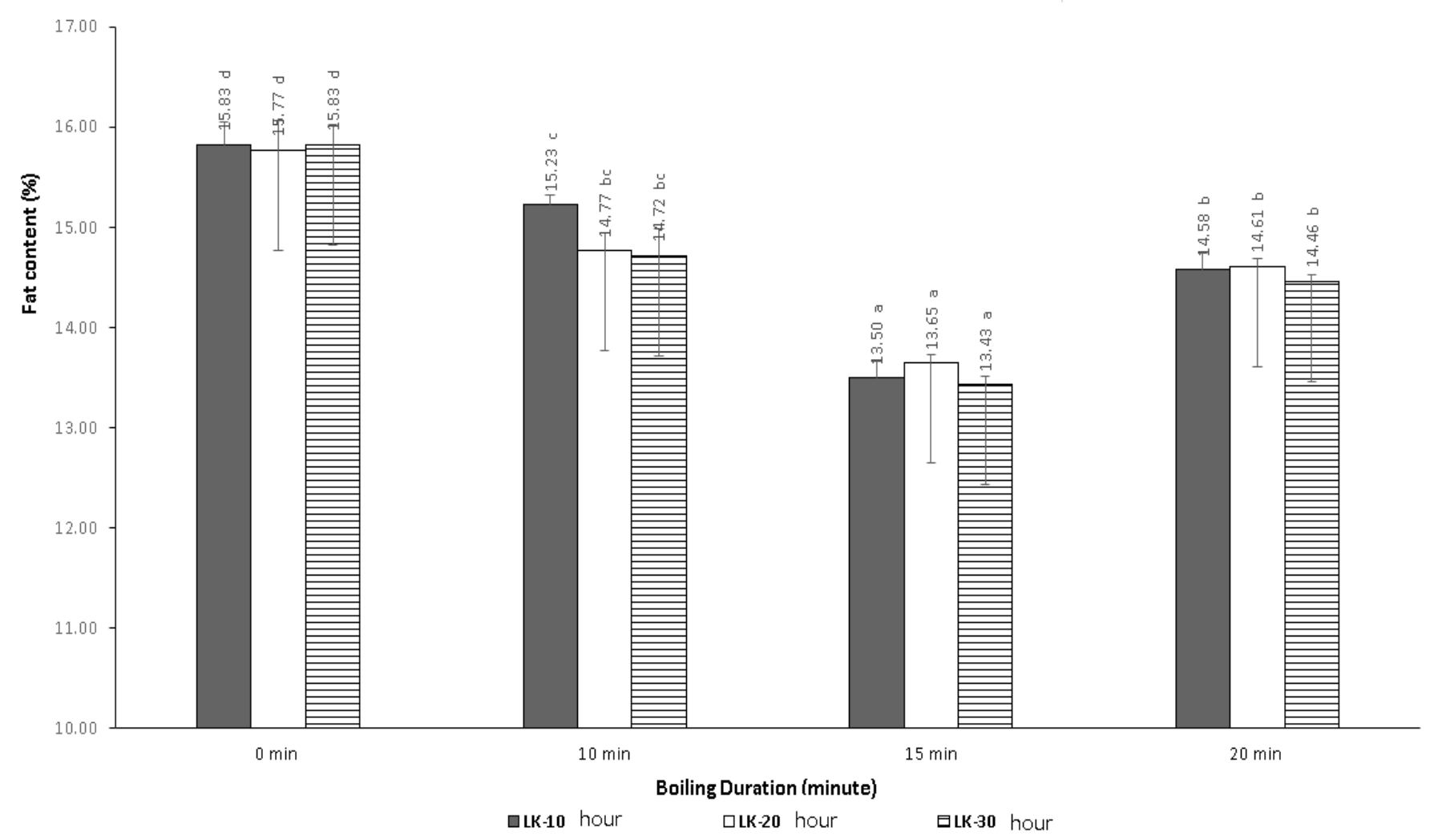

Figure 5. Graph of the fat content of white snapper fish skin rambak crackers. Description:DD = Drying Duration, the letter notation behind the value indicates a significant difference $\mathrm{p}<0.05$

\subsection{Fat Content}

Fatty levels of skin cracker crackers were derived more from the oil used to fry crackers that were left behind or trapped in the cracker structure. The fat content of white snapper fish skin rambak crackers based on boiling and drying duration can be seen in Figure 5.

The results of testing the fat content of rambak crackers from white snapper fish skin with a long boiling and drying treatment obtained fat content ranges from $13.43 \%-15.83 \%$. Figure 5 showed the fat content tend to decrease in the boiling process until the 15 th minute and has increased again in the 20th minute. The phenomenon of this fat content was the same as the phenomenon of fracture strength and the phenomenon of enlargement capacity of the white snapper fish skin rambak cracker.

A decrease in the fat level of the rambak crackers could be caused by the density and porosity of the skin, where the skin that was denser, which has less developmental power, would hold more oil than skin with large flower development.

In addition, it was also suspected because of drying with unstable sunlight, and according to Trivina et al. (2015), high levels of fat in crackers from fish skins could be caused by fish skin having a higher fat content as well. There was no standard fat content in fish crackers or skin crackers.
When compared with cow skin, rambak crackers, which have a fat content of $32.44 \%$ and buffalo skin rambak crackers $31.81 \%$ (Nadia, 2005), white snapper cracker skin crackers have lower fat content.

\section{Conclusion}

The boiling and drying duration effect on the chemical-physical properties of the white snapper fish skin rambak crackers. The resulting skin crackers have physical characteristics of 15.13-25.39 N / m2, fracture strength of $70.44-100.07 \%$, and chemical characteristics of water content of $1.09-4.95 \%$, protein content of $65.26-70.43 \%$, and fat content of $13.43-15.83 \%$. The best white snapper fish skin rambak crackers were obtained from the process of boiling time of 15 minutes and drying time of 30 hours with the lowest fracture value of $15.13 \mathrm{~N} / \mathrm{m} 2$, the highest enlargement power of $100.07 \%$, the lowest moisture content of $1.09 \%$, the highest protein content of $66.25 \%$, and the lowest fat content of $13.43 \%$.

\section{Acknowledgement}

All Author are grateful to Yuniwaty Halim for helping us to participate in writing this manuscript

\section{Authors' Contribution}

First Author, devised the main conceptual ideas, 
drafted and wrote the manuscript while second authors, colleted data, and critical revision of the article.

\section{Conflict of Interest}

All the authors of this review declare that they have no conflict of interest.

\section{Funding Information}

No direct funding was received for this work

\section{Reference}

Agustina, T., \& Saputro, D.D. (2018). Pengolahan kerupuk kulit ikan di Kelurahan Bulu Lor Kota Sema rang. Rekayasa, 16(1): 113-118. doi: 10.15294/ rekayasa.v16i1.15097

Amertaningtyas, D. (2011). Mini review pengolahan kerupuk rambak kulit di Indonesia. Jurnal Ilmu Ilmu Peternakan. 21(3): 18-29. ISSN: 0852-3581

Ariyanti, M., Dewi, A.P., Hapsari, \& Mashadi, S. (2018). Perbandingan kadar kolagen cangkang kerang darah (Anadara granosa) dengan cangkang kerang hijau (Mytilus viridis) di Bandengan, Kendal, Jawa Tengah. Jurnal Pharmascience, 5(2): 134-142. ISSN-Online. 2460-9560.

Badan Standarisasi Nasional Indonesia (BSN). (1996). Persyaratan Mutu Kerupuk Rambak. Jakarta : SNI (01-4308-19961.

Badan Standarisasi Nasional (BSN). (1999). Cara Uji Mutu Kerupuk Kulit. Jakarta: SNI 01-2713-1999.

deMan, J.M. (1999). Principle of Food Chemistry 3th Edition. Gaithersburbg, Maryland: Aspen Publisher Inc. ISBN 0-8342-1234-X

Fenema, O.R. (1996). Food Chemistry. 3th Edition. Madison Avenue, New York : Marcel Dekker, Inc. ISBN 0-8247-9691-8

Gadi, D.S., Trilaksani, W., \& Nurhayati, T. (2017). Histologi, ekstraksi dan karakterisasi kolagen gelembung renang ikan cunang Muarenesox talabon. Jurnal Ilmu dan Teknologi Kelautan Tropis, 9(2): 665 - 683. https://doi.org/10.29244/jitkt. v9i2.19300

Gilnatya, N. (2002). Pemanfaatan kulit tuna mata besar (Thunnus obesus) sebagai bahan baku kerupuk kulit. Skripsi. Bogor: FPIK Institut Pertanian Bogor.

Gunawan, F., Suptijah, P., \& Uju. (2017). Ekstraksi dan karakterisasi gelatin kulit ikan tenggiri (Scomberomorus commersonii) dari Provinsi Kepulauan
Bangka Belitung. Jurnal Pengolahan Hasil Perikanan Indonesia, 20(3): 568-581. DOI: https:// doi.org/10.17844/jphpi.v20i3.19814

Harsono, W. (2006). Pengaruh perbandingan daging ikan lele dengan tepung tapioca terhadap mutu kerupuk ikan yang dihasilkan. Skripsi. Jambi: Fakultas Pertanian, Universitas Jambi.

Hartati, F. K. (2018). Alternatif pengganti boraks pada pembuatan kerupuk puli. Jurnal Teknik Industri Heuristic, 15(2): 99-114.

Huda, N., Asikin, A.N., \& Kusumaningrum, I. (2016). Pengaruh konsentrasi asam asetat $(\mathrm{CH} 3 \mathrm{COOH})$ terhadap karakteristik fisikokimia kerupuk kulit ikan belida (Chitala sp.). Jurnal Ilmu Perikanan Tropis, 21(2): 1-8. ISSN 1412-2006

Kaewmanee, T., Karilla, T.T., \& Benjakul, S. (2015). Effects of fish species on the characteristics of fish cracker. International Food Research Journal, 22(5): 2078- 2087. ISSN (Online): 2231 7546

Khamidah, Sumardianto, \& Wijayanti, I. (2015). Pengaruh penggunaan binder alami pada proses finishing terhadap kualitas kulit ikan nila (Oreochromis niloticus) samak. Jurnal Pengolahan dan Bioteknologi Hasil Perikanan, 4(3): 7-13. e-ISSN 2442-4145

Kolanus, J.P.M., Hadinoto, S., \& Idrus, S. (2019). Karakterisasi kolagen larut asam dari kulit ikan tuna (Thunnus albacores) dengan metode hidroekstraksi. Jurnal Riset Teknologi Industri, 13(1): 99-110. DOI: http://dx.doi.org/10.26578/ jrti.v13i1.4994

Krishnamoorthi, J., Ramasamy, P., Shanmugam, V., \& Shanmugam, A. (2017). Isolation and Partial Characterization of Collagen From Outer Skin of Sepiapharaonis (Ehrenberg, 1831) from Puducherry Coast. Biochemistry and Biophysics Reports of Journal, 2017: 39-45. https://doi. org/10.1016/j.bbrep.2017.02.006

Kristianingrum, S., Arianingrum, R., \& Sulastri, S. (2006). Pemanfaatan limbah kulit ikan menjadi kerupuk (Rambak). Inotek, 10 (1) :13-25. e-ISSN: 2620-6404.

Muin, A.N. 2014. Pengaruh perbedaan bagian kulit dan lama perendaman dalam larutan asam cuka terhadap kualitas kerupuk kulit kerbau. Skripsi. Makasar: Jurusan Produksi Ternak, Fakultas Peternakan, Universitas Hasanudin.

Nadia, L. 2005. Nutrisi dan beberapa kriteria halal kerupuk kulit Jangek. Jurnal Matematika, Sains, dan 
Teknologi, 6(2): 100 - 107

Nasution, A.Y., Harmita, \& Harahap, Y. (2018). Karakterisasi gelatin hasil ekstraksi dari kulit ikan patin (Pangasius hypophthalmus) dengan proses asam dan basa. Pharmaceutical Sciences and Research, 5(3): 142 - 151. DOI: 10.7454/psr. v5i3.4029

Nurwahyuningsih, V. (2010). Pemanfaatan air rebusan ikan tongkol (Euthynnus affinis) sebagai bahan pembuatan kerupuk. Skripsi. Bogor : Departemen Teknologi Hasil Perairan, Fakultas Perikanan dan Ilmu Kelautan, Institut Pertanian Bogor.

Oktaviani, I., Perdana, F., Nasution, A.Y. (2017). Perbandingan sifat gelatin yang berasal dari kulit ikan patin (Pangasius hypophthalmus) dan gelatin yang berasal dari kulit ikan komersiil. Journal of Pharmacy Science, 1(Des) : 1-8. E-ISSN : 2615-1006

Purnamayati, L., Dewi, E.N., Sumardianto, Rianingsih, L., \& Anggo, A.D. (2018). Kualitas kerupuk kulit Ikan nila selama penyimpanan. Jurnal Ilmu Pangan dan Hasil Pertanian, 2(2): 162-172. Doi : 10.26877/jiphp.v2i2.3216

Rosiani, N., Basito, \& Widowati, E. (2015). Kajian karakteristik sensorik fisik dan kimia kerupuk fortifikasi daging lidah buaya (Aloe vera) dengan metode pemanggangan menggunakan microwave. Jurnal Teknologi Hasil Pertanian, 8(2): 84-98. E-ISSN 2614-7920

Rostini, I. (2013). Pemanfaatan daging limbah filet ikan kakap putih sebagai bahan baku surimi untuk produk perikanan. Jurnal Akuatika, 4(2): 141148. ISSN 0853-2523.

Salamah, E, Susanti, M. R., \& Purwaningsih, S. (2008). Diversifikasi kerupuk opak dengan penambahan daging ikan layur (Trichiurus sp.). Buletin Teknologi Hasil Perikanan, 9 (1): 53-64. http://repository.ipb.ac.id/handle/123456789/29548

Safitri, D.N., Sumardianto, \& Fahmi, A.S. (2019). Pengaruh perbedaan konsentrasi perendaman bahan dalam jeruk nipis terhadap karakteristik kerupuk kulit ikan nila. Jurnal Ilmu dan Teknologi Perikanan, 1(1): 47-54. ISSN: 2685-3701.

Said, M.I., Murpiningrum, E., \& Asmi, N. (2016, 25 Agustus). Kajian penggunaan larutan jeruk nipis (Citrus aurantifolia) sebagai soaking agent pada proses produksi kerupuk kulit kerbau. Paper presented at the Seminar Nasional Peternakan 2,

Makassar: Fakultas Peternakan Universitas Hasanuddin Makassar. pp. 162-167.

Setiawan A, Hariyadi, P., \& Sumardianto. (2015). Pengaruh penggunaan gambir (Uncaria gambier) sebagai bahan penyamak pada proses penyamakan kulit terhadap kualitas fisik kulit ikan nila (Oreochromis niloticus). Jurnal Pengolahan dan Bioteknologi Hasil Perikanan, 4(2): 124-132. ISSN online : 2442-4145

Sugihartono. (2014). Kemampuan gelatin kulit ikan menggantikan gelatin mamalia berdasarkan sifat kimianya untuk industri pangan. Jurnal Riset Teknologi Industri, 8: 156-167. DOI: http://dx.doi. org/10.26578/jrti.v8i16.1631

Taufiq, M. I., I. Kusumaningrum, \& A. N. Asikin. (2015). Pemanfaatan ikan belida (Notopterus chitala) sebagai bahan baku pembuatan kerupuk kulit. Jurnal Teknologi Pertanian 10(2): 41-44. ISSN1858-2419

Trilaksani, W., Nurilmala, M., \& Setiawati, I.H. (2012). Ekstraksi gelatin kulit ikan kakap merah (Lutjanus sp.) Dengan Proses Perlakuan Asam. Jurnal Pengolahan Hasil Perikanan Indonesia, 15(3): 240-250. Doi : 10.17844/jphpi.v15i3.21436

Trivina, O., Pamungkas, B. F., \& Sutono, D. (2015). Karakteristik kerupuk dari kulit ikan belida (Chitala sp.). Jurnal Ilmu Perikanan Tropis, 20(2): 29-34. DOI: 10.17844/jphpi.2016.19.3.233

Widati, A.S., Mustakim, \& Indriana, S. (2007). Pengaruh lama pengapuran terhadap kadar air, kadar protein, kadar kalsium, daya kembang dan mutu organoleptik kerupuk rambak kulit sapi. Jurnal Ilmu dan Teknologi Hasil Ternak, 2(1): 47-56. ISSN : 1978 - 0303

Widyatami, L.E., \& Wiguna, A.A. (2016). Teknologi pengolahan ikan lele secara Zero Waste menjadi produk olahan kerupuk pada Ponpes Raden Rahmat Sunan Ampel di Kabupaten Jember. Prosiding Seminar Hasil Penelitian dan Pengabdian Masyarakat Dana BOPTN: 283-288. ISBN : 978602-14917-3-7

Zulfahmi, A.N., Swastawati, F., \& Romadhon. (2014). Pemanfaatan daging ikan tenggiri (Scrombemorus commerson) kerupuk berbahan dasr sagu dengan substitusi dan fortifikasi rumput laut. Jurnal Ilmiah Perikanan dan Kelautan, 2 (4): 174-179. 